\title{
The Views of Prospective Teachers on the Political Context of Education and Teachers Roles in the Classroom ${ }^{\mathrm{i}}$
}

\author{
Yalçın Özdemir \\ Faculty of Education, Niğde Ömer Halisdemir University, Turkey
}

Copyright $\mathrm{O} 2018$ by authors, all rights reserved. Authors agree that this article remains permanently open access under the terms of the Creative Commons Attribution License 4.0 International License

\begin{abstract}
The responses which can be given to the questions about whether education and teachers' roles and practices in the classroom have a political context and these responses are not independent of the way we make sense of education and politics. Therefore, the responses of the prospective teachers to these questions will also contribute to their understanding of the political context of the teaching and teaching profession. On the other hand, teacher candidates' views on the political context of education will also affect their way of teaching. Therefore, it is important to understand their views. For this reason, in this research it is aimed to reveal and understand the opinions of the prospective teachers about the education and whether the teacher roles or practices in the classroom are political qualities. The results of this research, the qualitative research approach, were obtained by the responses given to the question form prepared by the researcher. The question form was replied by the 36 teacher candidates, senior students of the faculty of education, 22 of whom were female and 14 were male students. The obtained data were analyzed with descriptive analysis technique and it was understood that the majority of the participants in the research concluded that the politics was related to the state / power. It has also been understood that most of the participants define education as a political phenomenon, whereas the participants think that the teachers' role in the classroom does not seem to be a political feature or should not be.
\end{abstract}

Keywords Political Foundations of Education, Political Context, Politics, Teaching Practices, Prospective Teachers

\section{Introduction}

Education is a reality that has many bases of a social, psychological, economic, political, historical, cultural etc.
At the same time, education is an institutional structure in which professional experiences are experienced for teachers or prospective teachers. In this context, the way in which teachers perform their teaching as one of the most important components of their education system is not independent from the way they grasp their teaching and teaching profession, except many personal characteristics of the teachers. So, understanding of how teachers perceive the relevant bases of education is important, on the one hand, for professional development of teachers, on the other hand, for the improvement of the quality of the education system, and more generally for social development. In this context, it is important to understand whether there is a political basis for education and whether there is a political context of the professional role or practices of teachers, especially in the classroom. The implications of education and the political context of teachers' role in the classroom are directly related to how the concept of politics is understood. For this reason, firstly, it will be meaningful to examine the concept of politics.

\subsection{Politics}

When reviewing the literature of what the politics concept is, there are many definitions of politics. For example; the concept of politics, the process of division of scarce resources [1] intervention of the state through parliament or ministers [2] sets of human activities that encompass decisions on authoritarian division of values, interests and costs [3] the acquisition and implementation of power and decision making [4]; conflict/combat [5], the process which is made compulsive by means of generalized and binding rules established by the society [6].

Similarly, Kingdom and Fairclough [7] also expresses that it is difficult to simply answer the question 'what is politics'. They think that rather than talking about the correctness of one of the right definitions such as the art of consensus on politics, the application of authority, the 
acquisition of power and the definition of the form of a kind of roundabout manner, politics is a concept that can be understood by examining from the versatile and diverse perspectives of the politics [7].

Although there are different definitions of what politics is, the dominant definition approach related to the concept of politics is as a phenomenon associated with and related to the state/power [8]. The prevalence of dominant approaches to the handling of politics with the state/ power, can be seen in many definitions related to the concept of politics in many different languages. When the definition of the concept of politics in many linguistic regulatory agencies or dictionaries is examined, it is understood that the concept is defined in the context of reproduction of power. For example, politics is defined as "the whole of the principles of organizing and realizing the activities of the State as purpose, method and content" in the Turkish Language Institute Dictionary [9]. In the Cambridge English dictionary, the same comprehension can be seen when the definition of politics is examined; "politics is "the activities of the government, members of law-making organizations, or people who try to influence the way a country is governed" [10]. In both dictionaries, politics is clearly associated with the state/ power. However; while the definition of politics in Turkish dictionary limits political subjects only to the components of institutional power, in the English dictionary, it seems that the individuals who might influence the government might be political subjects.

\subsection{The Politics of Education and Teaching Practices in Classrooms}

The conceptualization of the concept of politics, it can inevitably affect education and therefore the understanding related to the politics of teaching roles. On the other hand, our way of making sense of education and teaching that will shape our understanding of whether education is political or not should be emphasized. So, it will not be possible to talk about a single universal "correct answer" that may be valid everywhere and at all times about whether education and teaching roles are political.

It is very difficult to come across studies in the literature that specifically examine the views of educators regarding/related to the politics of education and teaching roles. Although there is not a study that has been done directly on this subject, in some studies [11], it is understood that prospective teachers think that one of the most important problems of Turkey's education system is the intervention of politics on education. In other words, in the literature, there are studies rather than political bases of education, these studies are presented as a finding about their ideas on the education-politics relations. On the other hand, it seems that the related issues have been intensively handled, especially in theoretical discussions.
When the relevant debates are examined, it is particularly important that there are two different approaches that are contradictory. One of these approaches suggests that education and teaching roles are political, while the other view is strongly opposed to it.

It can be said that the idea which claims that education and politics are two unrelated realities is not new. For example, Hernandez's [12] work in 1965, as an example of some opinions that politics should be kept out of education; In Hillsborough County, she passes the following expressions on a School Board Minutes: "Let's keep politics out of education and education out of politics, don't soil our children by contact with politics, school people have a big enough job without mixing in politics" and "Don't make a political football out of our schools" [12]. Smith and Gallagher [1], also pointed out that among professional educators, researchers and society in general, the idea which claims education is an out of politics phenomenon is dominant. According to the authors [1], the reason for this form of thinking is that education is regarded as a noble initiative whereas politics is related to conflict. The understanding that teachers role in the educational process, including classroom roles should not have any political character is likewise closely related to the using the concepts of 'politics' and 'political' increasingly in a pejorative context. Ginsburg [13] state that educators generally avoid politics or at least they look for ways to put a distance between their public perceptions and politics. Therefore, in general, it is considered as a controversial phenomenon that the teaching profession has any political context [14].

In spite of the approaches, which regarded politics in a pejorative context and which claim that education and teaching should be excluded from politics and considered them only as a technical phenomenon, it is also possible to find approaches that emphasize the political nature/context of education and teaching. For example, it is claimed that the professional learning of teachers is carried out within the power, influence and control phenomena, and thus the understanding of the professional development of teachers cannot be realized outside this framework [15]. Similarly, it is stated that the daily professional experiences of teachers are realized in power relationships and influenced by these power relations, thus expressed as a "micropolitical" context and the understanding of this context is one of the most important components for understanding the world of teachers [16]. It is also stated that, the schools where the teachers experience their professional life are political due to the practical application of the state's educational policies and reflecting the relations of authority in these politics [17].

On the other hand, it is said that teachers 'roles in the classroom are political, because teachers' ways of using teacher authority in classrooms and their interactions with pupils can reproduce the socio-economic and cultural 
differences and inequalities among pupils [18]. It is stated [19] that educational processes are also political because the interactions between teachers and administrators and between teachers and students reflect power relations and are related to power. It has been argued that the classroom climate, in which the teachers will form with the classroom management attitudes in the classroom, can influence the future political participation processes of the students [20] and therefore the teacher roles in the classroom are political. For a similar reason, it is stated [21] that the content related to citizenship in curricula, the degree to which citizenship skills are gained in educational processes, and the dimensions such as class climate constitute the political context of educational institutions. Also, it is pointed out that the culture transferred to the students in the educational process reflects and reproduces the dominant culture belonging to a certain group in the society and for this reason it is said that education is political. In this context, it is indicated that teachers have political functions [22] because they contribute to this reproduction process through hidden curricula in their classes.

When approaches are examined whether education and teacher roles in the classrooms are political, it is understood that the relevant approaches mainly reflect different perspectives on education, teaching and politics. Therefore, a discussion about whether there is a political dimension-base of education/teaching, or a discussion about whether education could be handled as the political phenomenon will also contribute to the analyzing of perspectives on education and teaching. As stated before, there is no empirical study on the opinions of prospective teachers or de facto teachers about the related subject in the literature. In this respect, it is hoped that this work will contribute to the elimination of this deficiency in the area. In this context, the aim of this study is to understand the prospective teachers' views on the political context of education and the roles of teachers in the classroom.

\section{Materials and Methods}

This research aims to understand "what" the opinions of prospective teachers are about the political nature/ context of education and about political context of the roles of teachers in the classroom and reveal how they think so. Qualitative researches aim to understand the reality and define it as it is, so these researches focus on the question of "what" and "how" rather than "why" [23]. In this context, qualitative research approach has been adopted in this research due to its suitability for the purposes of the research. Rather than making any generalization from the views of the participants, attempts have been made to reveal thinking processes that build the subjectivities and subjectivities of the participants.

\subsection{Study Group}

Those who study at the last grade of the education faculty experience their student roles. These students are in the faculties of education in Turkey, also experience teacher roles in their internship of teaching. So they experience also students' roles and teacher roles in same year. In this context, their views and evaluations on the issues examined in this research are important for the purposes of the research. For this reason, it has been decided that the study will be carried out with the senior students of the education faculty. There was no desire for generalization in the study. On the contrary, it has attempted to understand the different subjectivities of the participants about the questions of the study. Thus, the study group of the study was determined by the convenience sampling technique, which is one of the purposeful sampling techniques. The convenience sampling is based on items that are completely available, quick and easy to reach [24]. The study group of this research is composed of 36 students who were continuing their education in the fourth grade at Turkish Education department at a state university in the 2014-2015 academic year in the Central Anatolia region of Turkey. 22 of participants are female and 14 are male. The willingness of the students to participate voluntarily was taken into account so, all students who volunteered to participate in the study were included in the study group.

\subsection{Data Collection Tools and Process}

Semi-structured question form was used as data collection tool in the research. In order to develop the question form, literature review was conducted first. Since no empirical studies on the research subject were found in the literature, the questions to be included in the form were prepared on the basis of theoretical studies and discussions. The opinions of the three field experts were consulted in order to understand whether open-ended questions in the form served for research purposes, whether they were understandable, and their applicability. In the next stage, pilot studies were carried out with two participants and the necessary changes were made in the question form. In the process of collecting data, the participants were informed of the purpose of working first and necessary explanations were given to them. Participants were asked to respond in writing to the questions "what is the politics", "whether education is a political phenomenon" and "whether the teachers have political roles in the classroom" through question forms. Getting the data in writing has some advantages such as, allowing more participants to be reached, allowing the participants to write their thoughts as they wish, and the ease of collecting and analyzing data [11]. It was also taken into consideration the nature of the questions asked by the participants and it was also taken into consideration that the participants may wish to see the research questions collectively. In this context, it was thought that it would be more appropriate for participants to give their answers in writing, not verbally. It took an average of 30 minutes for participants to respond to 
questions on forms.

\subsection{Data Analysis}

The answers given by the participants in writing to the research questions were first transferred to the computer environment by the researcher. In the process of analyzing data, descriptive analysis technique is used which is one of qualitative data analysis methods Descriptive analysis techniques involve the establishment of a framework for descriptive analysis, processing of data according to thematic framework, identification of findings and interpretation of findings [25]. Data which were transferred to the computer environment were read more than once and the participant responses were categorized on the basis of their similarities and differences and analyzed under different themes on the basis of the created framework. As a requirement of the qualitative research paradigm, there was no generalization concern in this research. On the other hand, some frequencies were included so that the weight of the tendencies in the participants' responses to some of research questions can be seen. However, these numerical values were not used as part of a cause-and-effect relationship but only as an indication of the weight of the response clusters. Some participants' statements were cited directly in order to reflect and interpret in detail the participant responses collected under different themes. Participants' names are coded and presented at the end of the citations. The coding was done by writing abbreviations indicating the participant number (for example Participant $1=\mathrm{P} 1$ ) and participant sex $($ For example Female $=\mathrm{F}$ and Male $=\mathrm{M})$ $(\mathrm{P} 1, \mathrm{~F}))$

\section{Findings}

Participants were asked three questions about what politics is, whether education is a political phenomenon, and whether there is any political function of the teachers in the educational process in the classroom, so prospective teachers' perspectives on the political bases of education and on the politics of teaching roles in the educational processes are tried to be analyzed.

\subsection{What Is The Politics?}

Participants' definitions about the politics are classified in three themes. These themes according to the order of most repeated definitions are, "politics as the execution/reproduction of the power", "politics as the ideas (ideological)" and "politics as method-strategy-techniques". The participants' definitions about politics which are in the theme of "politics as the executions/reproduction of the power" associated politics with the practices which belongs to the institutional power and its components like state, government and bureaucracy. In the other side it is very interesting that, participants' definitions in the themes of "politics as ideas" and "politics as method-strategy-techniques" mostly pointed out that these ideas or method-strategy or techniques are not any ideas-methods-strategy or techniques, instead which related to institutional power. In the other words, even though participants defined politics in three different ways, they severely defined politics as something which is related a political agent (institutional power and its components).

\subsubsection{Politics as the Execution/Reproduction of the Power}

The definitions about the politics which is most repeated $(\mathrm{f}=13)$ by the participants pointed out politics as practices of power/governing. Most of the participants specified that politics is a power/governing practice, and then they use different words to indicate power. Most repeated word was the "state" which is incarnational form of power in modern societies. So it can be said that these participants defined politics as the practices of the state:

[Politics] is the art of regulation and execution of state affairs... It is ability to guide to the state. The state invests in the future through politics. (P14, M)

[Politics] is the applications of the states' which are applicated in the social, cultural areas and which considers benefits of states or society. (P5, F)

[Politics] is a concept which takes on the task of establishing the social order and governing the society. It is created by the state to keep society together through a hierarchical system. (P9, F)

On the other hand, although some of the participants defined politics as a practice of governing-practice of managers like mentioned above, they defined the managers namely agents of the governing differently. For example one of the participants said that,

"[Politics] is a process involving the acts of the state or the government about an issue or acts state or the government want to do in the future" (P29, M).

So it is clear that this participants added government as a political agent near the state. Another participant said that:

[Politics] is the execution of the whole set of the rules which is constituted by the bureaucrats to provide order... It has got positive and negative aspects and it had been adopted by the state to prove the order. (P25, F)

By these statements, P25, F defined bureaucrats as political actors. As can be seen from the above statements, in the most repeated definitions politics is defined as the execution of the power or a practical strings which is needed for the reproduction of the power. So this conceptualization of politics is compatible with the hegemon ideas about politics [8].

Most of the participants who define politics as practices 
of the institutional power (state, government, bureaucrats etc.) gave a positive meaning to politics because of thinking that "politics is about common good" or "politics enables development". On the other side while two participants did not give any positive or negative meaning to the politics, four participants' definitions of politics had a kind of critical thoughts on it. It can be said that participants' critics on politics is about thinking politics with "evil". For example, it is said that "Politics is typically about governing of the state. In politics, everything is permissible" (P34, M). Similarly one of the other participants said:

I'm thinking politics as something about managing or governing. But politics is more about cheating in and cheating for people's perceptions to manage people and suck advantage out of it. (P16, M)

It can be said that, definition of politics as practices/execution/reproduction of power (especially institutional power like state, government etc.) can be regarded as answers for the question of "who can be "legitimate" agents of the politics?", because if the politics is practices of the power then political agents have to be define as power or its components. So we can say that, all participants who define politics as practices/ execution/ reproduction of power regards and also limits political agents just with power and its components.

\subsubsection{Politics as Ideas or Ideological Ideas}

Second most repeated definitions ( $\mathrm{f}=11)$ about politics pointed out politics as ideas. The remarkable thing in this characterization way is most of the "ideas" which stated in this definition were about ideological ideas:

Politics is a concept which includes the ideas of the peoples (or someone's) about a statement. This concept represents any of the ideology, because, people who make politics also act according to his/ her ideology... Because politics are personal ideas or people's ideas, it can be cause for consensus or conflicts. But in anyway it can be said that it is prerequisite thing for all countries. It is the thing that keeps all countries alive. (P3, F)

Politics is peoples' ideas and acts of them which compatible with these ideas who have got different ideas. For example peoples who are interested of their countries and who wants development of their countries may have different ideas for the way for development. For example, some of them may think that development must be realize through investment in oil or guns while the others may think that development must be realize just by enhancing peoples and environment-nature. Nowadays there are peoples who have got different political ideas. In our country especially... $(\mathrm{P} 1, \mathrm{~F})$

[Politics] is the expression of every people's ideas and feelings about his/her lifestyles by the way which won't hurt the others. (P20, M)

When politics is defined as ideas, it can be thinking that everyone has got ideas so can be political agents. Thus, it is understood from the statements of participants that, most of the participants $(f=7)$ who defined politics as ideas, can be regarded everyone as political agents. On the other side, it is also understood that, some of the participants who define politics as ideas, did not defined politics by the contents of the ideas but instead by who own that ideas:

Politics is the ideas of statesmen. Their endeavoring for the country is in short for Turkey. But rightness of all of these can be discussed. (P32, F)

Politics can be defined as the order which political groups wants to execute and ideas which are defends by them. So politics can be differentiated for every group. The ideas, executions and practices which are realized and which are wanted to be realized are different. (P8, F)

As can be seen, even politics is defined as idea, it can also regarded as a phenomenon associated with institutional power.

\subsubsection{Politics as Method, Techniques or Strategies}

A few participants $(\mathrm{f}=6)$ defined politics as something which have equivalent with methods, techniques and strategies which are using for execution of any act. In this definition, it was seen that the tendency which define politics through power repeated again. For example, one participant defined politics with these words: "In my opinions politics is the methods which politicians implemented" (P17, F). Another participant defined politics in same way: "Politics is the all strategies, methods and techniques which are used by people who wants to govern the country" (P12, F). In another word, politics had been defined not around "what it is" but instead it had been defined through the political agents who use politics and this political agent was again powerful. In the other side, two participants did not related politics with power but with anybody:

[Politics] is the method which people used it to impose himself on another people or bring himself to the fore" (P22, F).

I will roughly say that politics is the way to which to reach the best ... (P26, F)

Besides the themes mentioned above a few participants try to define politics through moral statements. For example one of the participants said that "The politics is the art of conciliation of the conflict of interest or ideas. But in reality, it is a vehicle for justification of the robberies" (P4, M). So we can say that in this kind of definition, politics used in pejorative manner. For example one of them hinted that politics is something like 
talking out of both sides of your mouth:

Today, the concept of politics has turned into a race field where a good talker has won. Politicians are people who speak by choosing from among the things that people will like. Even in our everyday life when we say something that a person does not like, a friend of us can warn us like "if you could behave politically, you would not break his heart"... (P2, F)

When the answers given in the question of what the politics are collectively evaluated, it is understood that most of the participants $(\mathrm{f}=22)$ irrespective of whether their answers are in the themes of "politics as the executions-reproduction of the power", "politics as the ideas (ideological)" and "politics as method-strategy-techniques", comprehends politics as something which its' agent is power and which is about power. It was understood that only a few participants ( $\mathrm{f}=11$ ) defined politics as something which everybody can be its agent. Although not expressed as "power", three participants described politics by associating it with political parties or groups.

\subsection{Is Education A Political Phenomenon?}

The second question addressed to participants in the research is whether education is a political phenomenon. It was understood that when the responses of the participants were analyzed, approximately two-thirds of the participants understood education as a political phenomenon, whereas a third of them thought that education is not a political phenomenon or should not be a political phenomenon. But it has to be answered that what determines this answer. Related findings that are important for the purposes of the study are given below.

\subsubsection{Education as a Political Reality in the Sense of Being a Part of the Process of Reproduction of Power}

About two-thirds of participants $(f=22)$ stated that education is a political reality. It is understood that all participants who indicated that education is a political reality defined education as political because the educational reality was shaped by the powers and at the same time education helped the governments to maintain their assets or reproduce itself. In these participants' statements, the agents like state, government, the people who manage the country are used as indicator of institutional power. In the other side, participants pointed to different contributions of education to the reproduction process of the power. For example, some of them defined education as political because the educational reality was shaped in the context of the reproduction of the ideology. This ideology for some meant not any person's, group's, political party's or government's ideology but instead a country's ideology:
In educational processes, education programs are prepared and implemented according to specific policies. Politics is a system of ideas, values and judgment of a country. This systems need to be adapted to education. So educational policies in progress are the transfers of the ideological, cultural, customs and traditions of the country to education and learning... In addition to transferring information to the students in an educational institution, the material and spiritual customs, perspectives and value systems of the country should be given to the students... Education is not an area which only knowledge teaching is done. In my opinion, education is political... Of course the education will be influenced by the policies of the country. But this influence should not be politicized and transferred to the educational environment by the human community represented by a political party. It must be made by the absolute majority in the National Assembly, because education is not an institution to be politicized under the influence of a party or government. (P21, M)

It is noteworthy that in the above expressions, the political identity of education is accepted only in the context of state policy, whereas it is stated that politics which can be understood as a group's policy and education should not be related. This distinction can be explained by the fact that education is perceived not as an institution that serves the interests of a particular group but as an institution that serves the common interests of the whole society. Participants in similar conclusions pointed out that education is political because it contributes to the reproduction of the views, aims and structure of hegemonic thoughts of the country-state-nation:

Whatever the government's policy, government develops and sustains education in its own policy, because there is no universal understanding of education. Every nation evaluates education according to its own thinking. If it were not so, there would not be so many different educational practices in the world today. The understanding of education in Germany is of course not the same with the understanding of education in Iran. The main reason for this is the political understanding of those nations. (P29, M)

The concept of politics is closely related to the concept of education. The politics of a country determines its education. Every country has got educational policies. To me, education is a political thing. It is determined according to each country's own needs... (P31, F)

On the other hand, education also was defined as political, by the assumption that it undertakes the kind of human rearing task required by institutional power. Some participants, for example, expressed that education is political because the institutional power is achieved through education in the type of human that it wants to 
cultivate. In other words, the fact that the aims of education are determined by the governments is expressed as a sign of the political aspects of education:

[Education] is political, because the goals of the schools vary according to the interests of the country and the societies that the administrators at that time want to train. For example, the rulers of the country, if they want their students to grow up to be very democratic or very religious, the aims of education are determined accordingly. (P1, F)

There are specific management systems and insights. Consistent with these systems, the state first establishes "educational policies" in order to realize the aims of self-employment, so that it can eventually train the people who will help and maintain to the state... Education is political because its aims and scopes determined by the system. The concept of education is strictly political, because it is based on protecting the existing one from these or other threats. (P7, F)

In modern societies, education's mission of training individuals with dominant values and attitudes caused to be shaped of the curriculums and education programs according to these missions. Some participants stated that education is political because of the fact that curricula are shaped by institutional powers:

When you think of a country's education, the political view of that country is always important. Whoever is in the current administration, the education of the country goes to that direction. Contrary to what is generally believed, education should not be defined as something that is just an instruction which is done in schools to the students... Who is in the current administration, the education policy shifts in that direction. For example, For example, if the government of A is advocating an Islamist view, the religious content of the lessons in the schools is increased and the lessons taught thus turn into an Islamic structure... (P13, M)

The fact that education was described as a practice of power and therefore an object of politics also points to the conception which contains the notion that education has not got any autonomy and points to notion that everything about educational reality is determined. Indeed, many participants have stated that, education is political with the reason that all aspects of education determined:

One of the management tasks of politics is managing the education system. The education system is regulated by politics and studies for practice in education are done by politics. While education itself is not a political thing, it has led to its implementation and execution being political. While education itself is not a political thing, it has led to its implementation and execution being political. (P34, M)
Politics and education are two interrelated concepts. Educational policies, which the state has implemented, are shaped by those who are in control in the direction of their opinions and thoughts. For this reason, education is a political thing... $(\mathrm{P} 18, \mathrm{~F})$

Education is political. Although we deny it, we know this is the case... Origin of the education is politics. If we constitute and implement the functioning of education in the framework of the rules set by the politics we cannot deny the existence of politics where education is. (P25, F)

On the one hand the fact that most of the participants define politics as practices of power, and define agents of politics as power and its 'components, and on the other hand the fact that a large part of the participants (two-thirds) define education as a political thing because education is shaped and presented by the power are two findings consistent with each other.

\subsection{2. "Conflict" Against "Sterile" Space}

It was understood that one third of the participants ( $\mathrm{f}=$ 12) thought that education should or should not be political. The participants, who thinks that education is not or should not be political, expressed their view with two arguments. First, some participants considered education as an area in which no conflict, contention, or debate should occur, but politics, in a sense, is a disagreement, contention, and so on conflict, etc. with "negative" manner. Hence in these arguments, it is rejected to think education which is "sanctified" with politics which is "demonized":

When the words of education and politics are considered as a concept, they are two different concepts that are not really related to each other. Because politics may involve opinions accepted by certain people of the country and not accepted by certain people, in contrast to this, education is associated with positive changes desirable to everyone in human behaviors. These changes in behaviors have to be beneficial to all of the society and country. From this point of view, there is no relation to each other. (P3, F)

... In today's politics, rather than the supremacy of common values, the superiority of certain people's own personal thoughts is concerned. For this reason, we cannot say that education and politics are the same concepts today. We should not say. If such a conclusion is reached, the first situation that will arise will be generation gap, conflict, and an inexplicable past. (P20, M)

In the second argument, firstly there is a consideration of politics as "educational policies". Then this relationship or in other words, the political aspect of education is rejected by saying that education is damaged by the cause of education policies which change very frequently: 
Education is definitely not a political thing. Education applied in a country should not be something that will change according to the pleasure of any politician. Because education is something stable. When I say stable things, I do not mean not to follow innovations and developments. It is something there is always and will be. It is not possible to limit education with the politics which applied by the rulers. If so, every newcomer will implement a new policy and education will really turn into a salad. (P2, F)

... Since political policies are short-lived, it causes constant change of education policy and society is again affected negatively. The relationship between education and politics should not include anything except give quality education to individuals, because if education and politics are meddling in each other, the country can be dragged into chaos. The educational policy should be aimed at social education and development, not political. (P28, M)

As we have seen, the above arguments are largely based on the understanding that the positive meanings attributed to education and the pejorative meanings attributed to concept of politics cannot be brought together or should not. In this context, it can be argued that functionalist approaches which defend that education is a neutral reality that serves to reduce and eliminate social contradictions, thereby serving the benefit of society as a whole and conveying the common values of society to individuals, comply with the notion that education is apolitical. On the other hand, in this form of comprehension, the knowledge that is tried to be taught in educational processes is also grasped as "objective" which is universal and insulated from the value, and scientificness is emphasized by making a distinction between science and politics. This positivistic approach therefore scrapes education from its social context and reduces it to a technical process.

\subsection{The Political Context of Teachers' Roles and Practices in the Classrooms}

The final question addressed to participants is about whether teachers' role and practices in classroom have a political character, in other words whether they are political or not. When the answers were analyzed, it was understood that only one third of the participants indicated that teachers had a political role in the classrooms, whereas two-thirds of participants thought that there is not any political function and role of the teacher in the classroom and should not be.

\subsection{1. 'Do not Pollute Education with Politics'}

With statements like "they have not" "they should not have" and "they have but they should not have", nearly two-thirds of the participants answered negatively to the question whether teachers' have any political role or practices in the classroom.
Part of the participants who seemed to have a negative attitude about the teachers' political roles in the classroom, stated that in reality, some teachers have a political attitude in classrooms as opposed to what they should have. According to some of them, having a political role or attitude is a "work" of someone who has got right of engaging with politics. According to these participants, having a political role or attitude is a "job" of someone who has got right of engaging with politics or doing policy.

In my opinion, teachers should not have any political role in the classrooms. Because the job of the teacher is to teach the students something, not educate them as politicians. (P33, M)

There is not any political role or function of the teachers in the classrooms. The teacher is the person who presents the knowledge to the students and the student is the person who gets the knowledge. For this reason I do not think they have a political role. (P30, F)

When I evaluate the present situation, I think that some teachers have a political role. But I think that they should not have. Teacher is a person of education. He should not be unaware of politics. He must be relevant. But he should not be a political personality, because the persons who are political are the people who rule the society. Teachers should not be political because they are in the community educating society. Teachers should be aware of their responsibilities as a training person and should do their job as they should. (P17, F).

As can be seen from the above expressions, some of the views that teachers should not have a political role are related to the grasp of politics as power and something which is only certain people can do it. Notion that teachers should not have political role is related to the grasp of politics as power and comprehends politics as something which is only certain people can do it. The concept of "politician" suggests that politics is an activity field or a profession in which a particular group is empowered to perform. And it is argued that teachers cannot enter this field of activity in a sense. Education was depicted by impartiality and exemption from values and described as a field of common interests, whereas policy is depicted as a field of bias, conflicts and personal interests. By this way clear attitude was displayed towards not to thinking them as two interrelated phenomenon, in another words any political aspects of education or teaching was rejected.

The second reason for the rejection of the political context of the teaching roles in the classroom is due to the contradiction between the prevailing conceptualizations of education (sacralisation) and politics (demonization) which described earlier. Education is depicted as impartiality, exemption from values and as a field of 
common interests, whereas policy is depicted as a field of bias, conflicts and personal interest. By this way a clear negative attitude was displayed towards bringing them together and rejected political aspects of education or teaching. Thus, some participants tried to clarify their notions that teachers' roles and practices in the classrooms should not be related to politics by repeating the arguments that education should not be political:

My teacher is my guide. Teacher is a north star that everyone can see even in a dark and lightless night. A teacher is someone who shares his knowledge with someone without discriminate, teaches humanity to his students without being fed up, even if he has been hurt thousands of times. Putting teachers into a political mould means turning that pole star into a light that only certain people can see. The words used by the teachers and behaviours that they do should be compatible with common values. Because the teacher is saint holy, blessed and democratic. In other words, the teacher is not the superiority of one side, but the divine proportion that each value meets in the name of humanity. It is never not right for the teacher to express a political value (!).(P20, M)

As can be seen from the above quotation, the relationship between the teacher who was conceptualized as a "saint" who works for "everyone" and politics which was conceptualized as a thing which does not aim common good was damned. In the following quote, the same logic continues in the context of the concept of freedom:

In my opinion teacher should not have any role that political. But this is the case with most schools and classrooms today. They should not have because, classrooms are free environments and an active communication should be between teacher and students. The concept of politics is preventing it. But where the concept of the state is, the concept of politics is inevitable. $(\mathrm{P} 10, \mathrm{~F})$

In the following two narratives, the dualism of education and politics which participants claim to exist were maintained. This dualism was again dualism of "good" and "bad". It can be said that, some of participants think that teachers, as officials charged with working on behalf of the state, perform politics as a state practice. Nevertheless, the negative attitudes towards the political context of teachers' roles were maintained with the reason that politics would harm education:

There should not be any political roles of the teachers but there is. Inevitably, it is expected from the teachers to implement the education plans shaped by the state. The inconsistencies in these plans negatively affect the students, thus negatively affecting/ affects the teachers. As this system goes on like this, it will be like this. When we look from the other side, most teachers are trying to impose their political views on their students. This is already a sequence of mistakes in itself... What the teacher should do is to teach only universally and not to be involved in such initiatives. (P25, F)

The teachers are facing with a situation in which as if they are responsible for fulfilling the practices adopted by education system and therefore politics. But the teacher, in my opinion, in no way should reflect a political vision to the students in the classroom, because schools are places to raise good people. Schools should not be an environment which is organized for raising any advocate, militant and soldier of any view. No school should be the "back garden" of any political party. (P34, M)

It can be seen again that most of the participants conceptualized education as a phenomenon that serves to the common interest of the whole society. And therefore they described education as a field in which any conflict of interest and factionalization should not exist. This approach of the participants also coincides with functional paradigms in the sociology of education.

\subsection{2. "Teachers Have Got Political Roles"}

Nearly one-third of the participants stated that the teachers had a political role in the classroom. Some of these participants expressed their views with the assumption that "politics is an inevitable phenomenon for people". Accordingly, every teacher inevitably has a political role in the classroom as individuals with political thoughts:

A teacher is inevitably acting according to a political thought. Teachers impose a certain political thought on their students. While some teachers impose the general politics of the country, some impose their own political thoughts on their students. This attitude also brings with it a lot of negativity. (P3, F)

A teacher has a political role in the classroom. As a result, because he is also a human being, he can impose his thoughts on the class, willy-nilly... As I said, if the teacher can be temperate, he should have a political role in the classroom. (P32, F)

As can be seen, "the teacher who reflected his political considerations in the classroom inevitably" was approved by the condition that these "political considerations" were in line with the policies of the government and were within "certain boundaries", he was criticized otherwise. Contrary to participants who think that having political roles is an imperative arising from being a human, some participants stated that this is a preference and similar to the above mentioned participant statements, they stressed that the teacher's political role should not contradict government policies:

A teacher has, and should have a political role in the 
classroom. However, this teacher must convey the social values to the students, while at the same time expressing the lecture implicitly. These social values should not be the ideological-party views of the teacher or the teacher's view of the world. (P21, M)

Teaching in a classroom has a political context. However, this situation should be confine to the limits of the basic philosophy of national education. Having a political context of teaching roles within the classroom should not be understood as reflecting the teacher's own personal political views. If, for example, an education based on the principles of Atatürk is to be given here, the teacher should put his own opinion on the edge and do his / her profession... (P23, F)

Some of the few participants, who stated that teachers had political roles in the classroom, expressed their views with the reason that, politics is a strategy-method, and that education also includes these strategies and methods:

I think the teacher has a political context. When teaching and instructing, teacher has to apply a method. Without an educational attainment or goal a particular education is unthinkable. So, the teacher should conduct the teaching profession in the determined method and strategies. (P15, F)

\section{Conclusion and Discussion}

As a result of this study, it has been understood that most of the participants have defined politics in the form of activities carried out by a certain political subject (power/state and its components) to reproduce its own existence. A large part of the participants think that the state shapes education so that it can survive its own existence, and because of this, education is political. Despite these considerations, most of the participants think that teachers' teaching practices or roles within the classroom should not have any political context. In other words, participants think that education is political, whereas classrooms, educational processes in classrooms and teacher roles in classrooms must be apolitical.

The view which correlates politics with only institutional power and its components prevents to understand the power relations in the classrooms. So it prevents, the visibility of the political aspects of the, daily life in the classrooms and teachers' practices. Therefore, this view marginalizes the idea of a teacher, whose job and working practices is political. Thus, the views of teachers, students, or parents that may contradict institutional power about education become easily marginalized. On the other hand, this view is related to the paradigms that claim that education is or should be independent of all power relations, and reproduces them. Thus understanding the role of education in the reproduction of social contradictions and inequalities and the functions of teachers in this context are also becoming very hard. Education, on the other hand, is influenced by all the characteristics of the social structure in which it is involved, and it influences that structure. Therefore, education is influenced by the power relations that are inherent in the social structure in which it is located. The institutionalization of education is the result of these power relations in a sense. In the classrooms, teachers distribute the material and symbolic resources in the classroom among students with different economic, cultural and social profiles, each coming from different parts of the society. In this sense, teaching practices can be evaluated as political.

Classrooms are micro-societal structures. One of the most important factors affecting the classroom climate is teachers. Teachers can determine whether students will express themselves freely in classrooms. They can affect the interacting ways of students in classrooms. They can also reproduce or reduce the inequalities among students. Thus, teachers who can create a democratic and open class climate will play an important role in the realization of democracy in the class and therefore in the development of democracy in society, and will contribute to the achievement of a more egalitarian society goal. It is therefore important that teachers have an awareness of the political contexts of their roles and practices in educational processes. It will be worthwhile to include training about the, political context of the education and teachers, in teacher education programs, to making such awareness.

While the pre-service teachers' opinions on the political context of education and teaching are related to macro-social structures in one aspect, they are also related to their everyday experiences. In this respect, it can be meaningful to conduct ethnographic studies on how teacher candidates experience the micropolitical context of teaching and education, especially during their internship. On the other hand, it can also be meaningful to conduct a similar ethnographic study with those who are already working as teachers.

\section{Acknowledgements}

I am very grateful to participants for their voluntary participation to this study.

\section{REFERENCES}

[1] Smith, J. K., \& Gallagher, D.J. (2008). An essay on the politics of schooling and educational research. Cultural Studies \& Critical Methodologies, 8(3), 284-301. https://doi.org/10.1177/1532708607310793.

[2] Maclure, S. (1976). Politics and education. Oxford Review of Education, 2(1), 17-26. 
https://doi.org/10.1080/0305498760020102

[3] Bob L. J. Jr. (1999). The politics of research-information use in the education policy arena. Educational Policy, 13(1), 23-36. https://doi.org/10.1177/0895904899131003

[4] Dadds, M. (2001) The Politics of pedagogy. Teachers and Teaching: Theory and practice, 7(1), 43-58. https://doi.org/10.1080/713698759

[5] Cohen, W.J. (1973). Policy and politics in education. The School Review, 82(1), 127-129 https://doi.org/10.1086/443121

[6] Kress, P. F. (1969). Politics and science: A contemporary view of an ancient association. Polity, 2(1), 1-13. https://doi.org/10.2307/3234085

[7] Kingdom, J., \& Fairclough, P. (2014). Government and Politics in Britain. Polity Press.

https://www.polity.co.uk/kingdom/pdfs/001.pdf

[8] Vergin, N. (2006). Siyasetin sosyolojisi: Kavramlar, tanımlar, yaklaşımlar. Ankara: Bağlam Yayıncılık.

[9] TDK. (2018). Politika. Retrieved from http://www.tdk.gov.tr/index.php?option=com_gts\&kelime $=\mathrm{POL} \% \mathrm{C} 4 \% \mathrm{~B} 0 \mathrm{~T} \% \mathrm{C} 4 \% \mathrm{~B} 0 \mathrm{KA}$

[10] Cambridge Dictionary. (2018). Politics. Retrieved from https://dictionary.cambridge.org/dictionary/english/politics

[11] Yılmaz, K., Altınkurt, Y. (2011). Öğretmen adaylarının türk eğitim sisteminin sorunlarına ilişkin görüşleri. Uluslararası İnsan Bilimleri Dergisi, 8(1), 942-973.

[12] Hernandez, D. E. (1965). Politics and education: Teachers and administrators in tampa campaign for adequate school budgets. The Clearing House, 40(3), 174-177. https://doi.org/10.1080/00098655.1965.11476940

[13] Ginsburg, M. B. (1997). Professionalism or politics as a model for educators' engagement with/in communities. Journal of Education Policy, 12(1-2), 5-12. https://doi.org/10.1080/0268093970120103

[14] Myers, J.P. (2009). Learning in politics: Teachers' political experiences as a pedagogical resource. International Journal of Educational Research 48(1), 30-39. https://doi.org/10.1016/j.ijer.2009.03.001

[15] Kelchtermans, G., \& Ballet, K. (2002). Micropolitical literacy: Reconstructing a neglected dimension in teacher development. International Journal of Educational Research,
37(8), 755-767.https://doi.org/10.1016/S0883-0355(03)00 069-7

[16] Troyna, B. (1994). The 'everyday world' of teachers? Deracialised discourses in the sociology of teachers and the teaching profession. British Journal of Sociology of Education, 15(3), 325-339. https://doi.org/10.1080/014256 9940150302

[17] Maguire, M., \& Ball, S. \& Braun, A. (2010). Behaviour, classroom management and student 'control': enacting policy in the English secondary school. International Studies in Sociology of Education, 20(2), 153-170. http://dx.doi.org/10.1080/09620214.2010.503066

[18] Hirschy, A.S., \& Wilson, M.E. (2002). The sociology of the classroom and its influence on student learning. Peabody Journal of Education, 77(3), 85-100.

https://doi.org/10.1207/S15327930PJE7703 5

[19] Grissom, J.A., \& Kalogrides, D., \& Loeb, S. (2015). The micropolitics of educational inequality: The case of teacher-student assignments. Peabody Journal of Education, 90(5), 601-614.https://doi.org/10.1080/0161956X.2015.10 87768

[20] Campbell, D.E. (2008). Voice in the Classroom: How an open classroom climate fosters political engagement among adolescents. Political Behaviour, 30(4), 437-454. https://doi.org/10.1007/s11109-008-9063-Z

[21] Torney-Purta, J. (2002). The school's role in developing civic engagement: a study of adolescents in twenty-eight countries. Applied Developmental Science, 6(4), 203-212. http://dx.doi.org/10.1207/S1532480XADS0604_7

[22] Acar, E. (2012). Hidden curriculum contributing to social production-reproduction in a math classroom. International Online Journal of Educational Sciences, 4(1), 19-30.

[23] Kümbetoğlu, B. (2005). Sosyolojide ve antropolojide niteliksel yöntem ve araştırma. İstanbul: Bağlam Yayıncilık.

[24] Baltac1, A. (2018). Nitel araștırmalarda örnekleme yöntemleri ve örnek hacmi sorunsalı üzerine kavramsal bir inceleme. Journal of Bitlis Eren University Institute of Social Sciences, 7(1), 231-274.

[25] Yıldırım, A., Şimşek, H. (2003). Sosyal bilimlerde nitel araştırma yöntemleri. (3rd ed.). Ankara: Seçkin Yayıncılık.

\footnotetext{
${ }^{\mathrm{i}}$ This article is an improved version of a paper presented at 26th International Conference on Educational Sciences (ICES 2017)
} 